\title{
Young Spanish Adults and Disinformation: Do They Identify and Spread Fake News and Are They Literate in It?
}

\author{
Aida María de Vicente Domínguez ${ }^{1}$, Ana Beriain Bañares ${ }^{2}\left[\right.$ and Javier Sierra Sánchez ${ }^{3, *}$ \\ 1 Department of Journalism, University of Malaga, 29100 Málaga, Spain; aidamaria@uma.es \\ 2 Department of Communication, Universitat Abat Oliba CEU, CEU Universities, 08022 Barcelona, Spain; \\ aberiainb@uao.es \\ 3 Department of Applied Communication Sciences, Complutense University of Madrid, 28040 Madrid, Spain \\ * Correspondence: javier_sierra@ucm.es; Tel.: +34-655232084
}

Citation: de Vicente Domínguez,

A.M.; Beriain Bañares, A.; Sierra

Sánchez, J. Young Spanish Adults

and Disinformation: Do They

Identify and Spread Fake News and Are They Literate in It?. Publications 2021, 9, 2. https://doi.org/10.3390/ publications 9010002

Received: 30 November 2020

Accepted: 5 January 2021

Published: 8 January 2021

Publisher's Note: MDPI stays neutral with regard to jurisdictional clai$\mathrm{ms}$ in published maps and institutional affiliations.

Copyright: $\odot 2021$ by the authors. Licensee MDPI, Basel, Switzerland. This article is an open access article distributed under the terms and conditions of the Creative Commons Attribution (CC BY) license (https:// creativecommons.org/licenses/by/ $4.0 /)$.

\begin{abstract}
The infodiet of young Spanish adults aged 18 to 25 was analysed to determine their attitude towards fake news. The objectives were: to establish whether they have received any training in fake news; to determine whether they know how to identify fake information; and to investigate whether they spread it. The study employed a descriptive quantitative method consisting of a survey of 500 representative interviews of the Spanish population aged between 18 and 25 through a structured questionnaire. The results indicate that they are aware of the importance of training, although generally they do not know of any course and when they do, they do not tend to enroll on one either due to lack of interest or time. These young adults feel that they know how to identify fake content and, moreover, that they know how to do so very well. However, they do not use the best tools. While they do not always verify information, they mainly suspect the credibility of information when it is meaningless. However, they do not tend to spread fake information. We conclude that media information literacy training (MILT) is necessary in educational centres that focuses on the main issues identified.
\end{abstract}

Keywords: fake news; young adults; Spain

\section{Introduction}

In the era of fake news, information consumption patterns require media literacy to empower citizens and help them acquire the media skills necessary to access, understand, analyse, evaluate, produce content and distinguish between real and fake news [1].

In addition to the problem of the immediacy with which it is generated and spread, various studies warn that it is also widely believed in society. If the report "Fake news, filter bubbles, post-truth and trust" [2] revealed that Spanish people were the most likely in Europe to believe fake news, forecasts do not indicate any improvements in the future because in 2022, according to the Gartner report [3], more fake information will be consumed than true. Thus, it is extremely important to determine whether young adults are equipped to deal with misinformation.

This study analyses young adults because they are the age group who most consume information in the digital environment $[4,5]$ and are "those who feel most vulnerable to fake news [ ... ]. Indeed, almost half of the people who believe they receive fake news are very often aged between 18 and 34 years old" [6].

In this study we analyse the infodiet of young Spanish adults between the ages of 18 and 25 to determine the filters they apply to the information they consume in order to avoid fake content. We analysed whether they spread fake content because the circulation of fake information is one of the complex problems that must be addressed. In this regard, the World Economic Forum warns that "the spread of disinformation online is one of the 10 global risks of the future" [7] p. 407. We examine whether they have received any kind 
of training to deal with fake news as it has damaging consequences for the political, social, and economic future and for daily decision-making, among many other things.

To mitigate it, mechanisms have been created in various spheres, including social networks, the European Union, and the United Nations Educational, Scientific and Cultural Organization (UNESCO). Media organizations have introduced fact-checking. These measures are of interest to the scientific community, with studies documenting the verification initiatives implemented at both the international level [8] and the national level, such as B de Bulo [9] or Maldita.es [10]. Work has also been carried out that has examined the variety of authentication methods, practices and tools aimed at users and media professionals to protect themselves from fake content and to ensure the quality of information presented taking into consideration the recent advances in multi-channel media storytelling and their potential in cross-modal veracity strategies [11].

The similarities and discrepancies between academic and professional discourse around fact-checking have also been analysed [12], as has the role journalistic deontology plays as a tool in the fight against fake information [13]. Such tools help define what some researchers are beginning to refer to as the future of journalism in post-truth times [14] or the new global media ecosystem suffused with fake information [15].

However, along with these initiatives it is also necessary to provide a solid education in fake news due to the amount of non-journalistic content disseminated on the Internet and consumed daily. Alonso [16] point to the need for media literacy across society to deal with information disorder. To this end, several training courses have been organised in Spain.

The modalities offered comprise courses that are seminars or workshops organised by educational or business institutions and taught by experts in the field or by those who work with verification platforms in Spain such as Maldita.es and Newtral, as well as in collaboration with Google after starting their verification workshop. There are also initiatives run by the European observatory for the analysis and prevention of misinformation (ObEDes).

These courses mainly analyse such elements as: the role played in society by fake news and post-truth; identifying the objective of fake news; investigating who is responsible for fake news; studying the models of propagation and distribution of fake news online; classifying the types of fake news; studying the formats and genres of fake news; learning how to detect and combat fake news; and understanding the concept of fake news, among other contents.

In this context, this research aims to provide data on young Spanish adults and their relationship with fake news. The goal is to provide significant data to create effective curricular programs that allow the adaptation from fast consumption to consumption that applies criteria to verify credibility and to examine issues relating to information to contribute to an ecosystem of reliable, responsible and transparent information.

\subsection{Literature Review}

\subsubsection{Concept: Fake News and Disinformation}

The Ethical Journalism Network (EJN) defines fake news as "information deliberately fabricated and published with the intention to deceive and mislead others into believing falsehoods or doubting verifiable facts" [17]. Such information, which according to the Cambridge Dictionary [18] is characterized by presenting itself as news, is "generally created to influence political opinions or as a joke". Amoros also considers that it poses as news "with the aim of spreading a hoax or deliberate misinformation to obtain a political or financial end" [19] p. 171.

Fake news is a concept that young Spanish people are well aware of. Mendiguren, Dasilva and Meso [20] reveal that young university adults understand fake news as: fake information that is intended to influence people's opinions; fake information usually spread through social networks in order to manipulate public opinion in the interests of those who 
spread it; news with fake information; or news with fake information that becomes so well known that many ends up accepting it as true without even corroborating it.

After conducting a review on how academic studies defined and put into practice the term fake news, Tandoc, Wei Lim, and Ling drew up a classification consisting of six types of fake news: "news satire, news parody, fabricated, manipulated, publicity and propaganda" [21] p. 141.

However, Martens, Aguar, Gómez and Mueller-Langer [22] highlight that there is no consensus regarding this term. Indeed, there are some who argue against using the term fake news, as it has an impact on the credibility of journalism because associating fake information with the news is a breach of the essence of journalism, which is to tell the truth about what happened. Therefore, it should be noted that "even if fake news has the appearance of journalistic news (headline, journalistic structure and appearing to have a reliable interface), fake news can never be considered journalistic content because it contravenes the journalistic essence" [23] p. 245, which is why an open debate on how to designate this type of information is considered necessary. Indeed, Rodríguez-Pérez proposed that it is better to use the term disinformation than fake news to address hoaxes, or misleading or malicious content for four reasons:

"Firstly, we highlight the simplification of the concept with regard to the complexity of disinformation; secondly, the oxymoron of the term fake news; thirdly, the discursive appropriation of the term by political leaders to discredit the media and journalists; and, fourthly, the intrinsic economic and ideological motivations associated with the generation of fake news" [24] p. 72.

The European Commission's Communication on tackling online disinformation [25] defines disinformation as "verifiably false or misleading information created, presented and disseminated for economic gain or to intentionally deceive the public" (para. 1), noting how "misinformation and fake news intervene in democratic processes such as elections and create a public opinion based on lies and false information that many people believe to be true" (para. 3).

Regardless of the term used, it is considered a danger to democratic life and a geopolitical threat [26]. The rise of fake news and disinformation is, therefore, one of the main issues to be addressed internationally.

\subsubsection{Young Adults and Fake Information}

Studies focused on young adults and fake news have mainly addressed one sector: university students. At the international level, the habits of Portuguese university students with regard to fake news have been investigated, including the criteria they adopt before sharing information and the perception they have of fake information $[27,28]$. Studies have also examined how Salvadoran students from the Monica Herrera School of Communication and the José Simeón Cañas Central American University inform themselves, process news and verify facts [29]. Similarly, the effectiveness of the courses taught on verification to students at the University of Florence has also been analysed [30].

However, academic interest in the university environment has not focused exclusively on young students but also on other sectors of the university community. For example, the study by Pineda et al. [31] examined the habits of consulting, comparing and verifying of news by students, teachers and administrative staff of the Tecnológico de Antiquioquía in Colombia, while Malaquías, Lizbeth, Pérez Rivera, Ramos and Villegas [32] compared young Mexicans aged between 18 and 30 years old with university education and those with only a basic education in order to establish whether people who do not study at university consume and share more fakes news.

In Spain - the subject of our study - the level of credibility that young university students studying a degree in Communication and Education at the Loyola Andalusia University give information has been investigated, revealing differences both in terms of gender and level of studies [7]. This field of study was expanded by Mendiguren, Dasilva, and Meso [20], who studied whether university students who study journalism at the 
University of the Basque Country knew how to identify fake news, if they believed they had the criteria to distinguish it, and how they verify information when they suspect that it lacks rigor, as well as the credibility they give mainstream media and the dissemination of news they trusted least.

The study by Catalina, Sousa and Cristina Silva [4] is also significant. They compared Spain, Brazil and Portugal in order to determine how future journalists inform themselves in the digital environment, the uses they make both for consulting and disseminating news, the degree to which they consider themselves capable of identifying fake information, where they believe most fake news is located, the reasons for its spread; and the degree of credibility they give to various media organizations.

In addition to these studies are various prominent research projects such as the one carried out by the University of Huelva, Granada and Vigo titled "Conspiracy Theories and Disinformation in Andalusia" [33], which analyses whether the current panorama, characterized by the proliferation of disinformation, paves the way for the creation and rapid dissemination of conspiracy theories among young Andalusian residents aged 18 and over.

The study presented here aims to provide data on the identification and dissemination of fake information by young Spanish adults and whether they have received any training in it. The results will be useful in helping to create effective curricular designs that provide them media information literacy training (MILT) that allows them to gain skills and attitudes to address fake news and disinformation.

\section{Materials and Methods}

\subsection{Study Design}

In order to determine the habits of young Spanish adults when faced with the reception of fake news, its dissemination, their level of literacy and the importance they give to being trained to detect fake news, we used primary data, namely data collected the first time and specifically to cover particular information objectives [34]. The data were gathered through a descriptive quantitative research design [35]. Specifically, a survey was carried out in which a structured questionnaire was sent to the entire Spanish population aged between 18 and 25 years, with a sample of $501^{1}$ panel interviews being conducted online between 23 July and 14 August 2020.

The study followed a quality control procedure in each of the processes. To guarantee the quality of the questionnaire design and its correct understanding, prior supervision was requested from three social science research professionals. To guarantee the quality of the fieldwork, we collaborated with the company Netquest, which has at its disposal a community of individuals who participate at single invitation only, thereby reducing the risk of self-selection and duplications and providing exclusive information. Moreover, this company holds an ISO 26362 certificate. Prior to carrying out all the field work, the questionnaire was piloted to check its suitability.

\subsection{Sample Design}

For the design of the sample [36], the weight of each sociodemographic segment in the Spanish population was sought according to the National Institute of Statistics, applying the same proportions to the scheduled 500 interviews. As the fieldwork was carried out, compliance with study quotas was verified. Therefore, the large sample size and the chosen sampling system allowed us to extrapolate results from the entire Spanish population between 18 to 25 years old, with a sample error of $\pm 4.47 \%$ and a confidence level of $95 \%$ (Table 1 ).

1 One more interview in addition to the scheduled sample were carried out and were included. 
Table 1. Sample distribution.

\begin{tabular}{|c|c|c|c|}
\hline & $\begin{array}{l}\text { Spanish Population } \\
\text { Distribution }\end{array}$ & $\begin{array}{c}\text { Number of } \\
\text { Predicted Interviews }\end{array}$ & $\begin{array}{c}\text { Final } \\
\text { Distribution }\end{array}$ \\
\hline \multicolumn{4}{|l|}{ Sex } \\
\hline Male & $51 \%$ & 255 & 255 \\
\hline Female & $49 \%$ & 245 & 246 \\
\hline \multicolumn{4}{|l|}{ Age } \\
\hline 18 & $11 \%$ & 53 & 51 \\
\hline 19 & $11 \%$ & 55 & 54 \\
\hline 20 & $11 \%$ & 57 & 58 \\
\hline 21 & $12 \%$ & 60 & 60 \\
\hline 22 & $13 \%$ & 63 & 64 \\
\hline 23 & $13 \%$ & 67 & 67 \\
\hline 24 & $14 \%$ & 69 & 72 \\
\hline 25 & $15 \%$ & 75 & 75 \\
\hline \multicolumn{4}{|l|}{ Region } \\
\hline $\begin{array}{l}\text { Northeast/Catalonia } \\
\text { and Balearic Islands }\end{array}$ & 10 & 50 & 50 \\
\hline Levante & 15 & 75 & 75 \\
\hline South/Andalusia & 21 & 105 & 106 \\
\hline Central & 10 & 50 & 50 \\
\hline Northwest & 8 & 40 & 39 \\
\hline North central & 7 & 35 & 36 \\
\hline Canary Islands & 2 & 10 & 10 \\
\hline MAB (Metropolitan area of Barcelona) & 11 & 55 & 55 \\
\hline MAM (Metropolitan area of Madrid) & 16 & 80 & 80 \\
\hline \multicolumn{4}{|l|}{ Social class } \\
\hline A1. High-high & 16 & 80 & 80 \\
\hline A2. High & 22 & 110 & 109 \\
\hline B. Medium-high & 16 & 80 & 81 \\
\hline C. Medium-medium & 23 & 115 & 120 \\
\hline D. Medium-low & 7 & 35 & 35 \\
\hline E1. Low & 13 & 65 & 65 \\
\hline E2. Low-low & 2 & 10 & 11 \\
\hline
\end{tabular}

Source: Authors.

\subsection{Questionnaire Design}

The first part of the questionnaire collected information on sociodemographic data such as sex, age, province, habitat, area, social class and educational level. Next, the central questions of the questionnaire were broken down into why fake news is generated, the ability to detect fake news, why a news story is considered fake, to what extent the news is checked and how this information is verified, how often fake news is disseminated and why, finishing with the importance and level of training in the verification of fake news.

\subsection{Statistical Methods}

The collected data was cross-referenced with sociodemographic variables to observe whether there were statistically significant differences between the various segments analysed. These segments were: sex, age, level of education (first grade, second grade, third grade), ${ }^{2}$ size of habitat (less than 50,000, more than 50,000 inhabitants), social class (high-high, high, medium-high, medium-medium, medium-low, low and low-low) and geographical area (Northeast/Catalonia and Balearic Islands, Levante, South/Andalusia, Cen-

2 First grade: No studies (incomplete primary studies); Primary school.Second grade: Secondary school up to 18 years (qualifications include the equivalent of UK GCSEs, A levels, BTECs).Third grade: Equivalent to Technical Engineer 3 years, University Schools, Technical Architects, Teaching, ATS, University Graduates 3-year course, Social Graduates, Social Workers, Bachelor, Master's, Doctorate. 
tral, Northwest, North central, Canary Islands, Metropolitan area of Barcelona, Metropoli$\tan$ area of Madrid) of the respondents. ${ }^{3}$

To determine the existence of statistically significant differences in the information obtained, a $t$-test of proportions was carried out, which allows for the comparison of cell by cell data of a table with category variables of independent samples [37]. This test compares the values between two cells of the same row with the columns of the table. For each column, the $t$-test was used on the hypothesis that the population proportion of case $\mathrm{A}$ and case $\mathrm{B}$ can be considered equal versus the hypothesis that they are significantly different (either much higher or much lower) at a 95\% confidence level. In the tables, significant statistical differences are represented with capital letters, which coincide with the column whose proportion is considered higher.

\section{Results}

\subsection{Literacy of Young Spanish Adults Regarding Fake News}

We found that $76.8 \%$ of young Spanish adults aged between 18 and 25 attach great importance to media literacy to prevent disinformation (very important $33.1 \%$, quite important $43.7 \%$ ). In particular, those who attach greatest importance to training in the verification of information and detection of hoaxes are young people over the age of 20 and those with a higher education. No statistically significant differences were observed in the rest of the segments analysed (Table 2).

Table 2. Question 15: How important is it to be trained in the detection of fake news?

\begin{tabular}{|c|c|c|c|c|c|c|c|}
\hline & \multirow[b]{2}{*}{ Total } & \multicolumn{3}{|c|}{ AGE } & \multicolumn{3}{|c|}{ EDUCATION } \\
\hline & & $\begin{array}{l}18 \text { to } 19 \\
\text { Years Old } \\
\text { (A) }\end{array}$ & $\begin{array}{c}20 \text { to } 22 \\
\text { Years Old (B) }\end{array}$ & $\begin{array}{l}23 \text { to } 25 \\
\text { Years Old } \\
\text { (C) }\end{array}$ & $\begin{array}{l}\text { No Studies } \\
\text { /First Grade } \\
(\mathrm{D} *)^{4}\end{array}$ & $\begin{array}{l}\text { Second } \\
\text { Grade } \\
\text { (E) }\end{array}$ & $\begin{array}{c}\text { Third } \\
\text { Grade } \\
\text { (F) }\end{array}$ \\
\hline \multirow[t]{2}{*}{ Total Individuals } & 501 & 105 & 182 & 214 & 6 & 290 & 205 \\
\hline & $\%$ & $\%$ & $\%$ & $\%$ & $\%$ & $\%$ & $\%$ \\
\hline Very important & 33.1 & 28.6 & 34.6 & 34.1 & 16.7 & 30.0 & 38.0 \\
\hline Quite important & 43.7 & 40.0 & 44.5 & 44.9 & 66.7 & 43.1 & 43.9 \\
\hline Somewhat important & 17.8 & 24.8 & 15.9 & 15.9 & 0 & 21.4 & 13.2 \\
\hline Not very important & 4.2 & 4.8 & 3.8 & 4.2 & 16.7 & 4.1 & 3.9 \\
\hline Not important & 1.2 & 1.9 & 1.1 & 0.9 & 0 & 1.4 & 1.0 \\
\hline Top Two Box & 76.8 & 68.6 & $79.1 \mathrm{~A}$ & $79.0 \mathrm{~A}$ & 83.3 & 73.1 & $82.0 \mathrm{E}$ \\
\hline Bottom Two Box & 5.4 & 6.7 & 4.9 & 5.1 & 16.7 & 5.5 & 4.9 \\
\hline
\end{tabular}

Source: Authors.

However, $76.2 \%$ of those interviewed were unaware of any literacy program, while $23.8 \%$ state that they knew of one, either as a result of their own initiative $(11.4 \%)$ or because they had been offered one (12.4\%). Young people with third grade studies were most familiar with this type of course. No significant differences were observed in the rest of the segments studied (Table 3).

3 The article presents the total data by age and by educational level since they showed the greatest differences, although all the aforementioned segments were analysed and the most relevant data will be indicated where necessary.

$\left.4 \quad{ }^{*}\right)$ Insufficient sample base for calculating statistical differences. 
Table 3. Question 16: Which of these statements best fits your situation regarding your training in fake news?

\begin{tabular}{|c|c|c|c|c|c|c|c|}
\hline & \multirow[b]{2}{*}{ Total } & \multicolumn{3}{|c|}{ AGE } & \multicolumn{3}{|c|}{ EDUCATION } \\
\hline & & $\begin{array}{l}18 \text { to } 19 \\
\text { Years Old } \\
\text { (A) }\end{array}$ & $\begin{array}{l}20 \text { to } 22 \\
\text { Years Old } \\
\text { (B) }\end{array}$ & $\begin{array}{l}23 \text { to } 25 \\
\text { Years Old } \\
\text { (C) }\end{array}$ & $\begin{array}{l}\text { No Studies/First } \\
\text { Grade } \\
\left(D^{*}\right)\end{array}$ & $\begin{array}{l}\text { Second } \\
\text { Grade } \\
\text { (E) }\end{array}$ & $\begin{array}{l}\text { Third } \\
\text { Grade } \\
\text { (F) }\end{array}$ \\
\hline \multirow[t]{2}{*}{ Total Individuals } & 501 & 105 & 182 & 214 & 6 & 290 & 205 \\
\hline & $\%$ & $\%$ & $\%$ & $\%$ & $\%$ & $\%$ & $\%$ \\
\hline $\begin{array}{l}\text { I know of a program or } \\
\text { course on how to check } \\
\text { news because I have } \\
\text { looked for one myself }\end{array}$ & 11.4 & 6.7 & 11.0 & 14.0 & 16.7 & 9.7 & 13.7 \\
\hline $\begin{array}{l}\text { I know of a program or } \\
\text { course on how to check } \\
\text { news because I have } \\
\text { been offered one }\end{array}$ & 12.4 & 15.2 & 13.2 & 10.3 & 16.7 & 10.7 & 14.6 \\
\hline $\begin{array}{l}\text { I don't know of any } \\
\text { program or course }\end{array}$ & 76.2 & 78.1 & 75.8 & 75.7 & 66.7 & $79.7 \mathrm{~F}$ & 71.7 \\
\hline
\end{tabular}

Regarding participation in a course or receiving training on how to detect fake news, among those young adults who were aware of any, $76.5 \%$ did not take part in any compared to $23.5 \%$ who received such training (Table 4 ). The courses undertaken were carried out mainly at university $(46.4 \%)$ (Table 5) and were mainly free (64.3\%) (Table 6).

Table 4. Question 17: Have you taken any course or had any training on how to detect fake news?

\begin{tabular}{cc}
\hline & Total \\
\hline Individuals Aware of a Course & $\mathbf{1 1 9}$ \\
\hline Have taken a course & $\%$ \\
Have not taken a course & 23.5 \\
\hline
\end{tabular}

Source: Authors.

Table 5. Question 18: Where did you do it?

\begin{tabular}{cc}
\hline & Total \\
\hline Individuals Who Have Taken a Course & $\mathbf{2 8}$ \\
\hline University & $\%$ \\
Institute & 46.4 \\
Other answers & 10.7 \\
Do not know / Do not answer & 25 \\
\hline
\end{tabular}

Source: Authors.

Table 6. Question 19: What was this course like?

\begin{tabular}{cc}
\hline & Total \\
\hline Individuals Who Have Taken a Course & $\mathbf{2 8}$ \\
\hline Free & $\%$ \\
Paid by student, family, friends & 64.3 \\
Grant & 21.4 \\
A college or degree course subject & 3.6 \\
\hline
\end{tabular}


The reasons why young people who, although aware of a course on how to detect fake news, did not take part in any, were basically because they were not interested (35.2\%), lacked time (14.3\%), especially those aged 20 to $22(20.6 \%)$, and because they believed that they already knew how to detect fake news (14.3\%) (Table 7).

Table 7. Question 20: Why have you not taken any course or training on how to detect fake news? (Do not suggest).

\begin{tabular}{|c|c|c|c|c|c|c|c|}
\hline & \multirow[b]{2}{*}{ Total } & \multicolumn{3}{|c|}{ AGE } & \multicolumn{3}{|c|}{ EDUCATION } \\
\hline & & $\begin{array}{l}18 \text { to } 19 \\
\text { Years Old } \\
\left(A^{*}\right)\end{array}$ & $\begin{array}{l}20 \text { to } 22 \\
\text { Years Old } \\
\text { (B) }\end{array}$ & $\begin{array}{l}23 \text { to } 25 \\
\text { Years Old } \\
\text { (C) }\end{array}$ & $\begin{array}{l}\text { No Stud- } \\
\text { ies/First } \\
\text { Grade } \\
\left(D^{*}\right)\end{array}$ & $\begin{array}{l}\text { Second } \\
\text { Grade } \\
\text { (E) }\end{array}$ & $\begin{array}{l}\text { Third } \\
\text { Grade } \\
\text { (F) }\end{array}$ \\
\hline $\begin{array}{c}\text { Individuals Who Know of } \\
\text { Courses but Have Not Taken } \\
\text { Any }\end{array}$ & 91 & 17 & 34 & 40 & 2 & 49 & 40 \\
\hline & $\%$ & $\%$ & $\%$ & $\%$ & $\%$ & $\%$ & $\%$ \\
\hline I'm not interested & 35.2 & 35.3 & 47.1 & 25.0 & 50.0 & 42.9 & 25.0 \\
\hline I don't have time & 14.3 & 23.5 & $20.6 \mathrm{C}$ & 5.0 & 0 & 16.3 & 12.5 \\
\hline $\begin{array}{l}\text { I already know how to } / \mathrm{I} \text { have a } \\
\text { program }\end{array}$ & 14.3 & 5.9 & 14.7 & 17.5 & 0 & 14.3 & 15.0 \\
\hline I don't have any money & 1.1 & 0 & 0 & 2.5 & 0 & 0 & 2.5 \\
\hline $\begin{array}{l}\text { There are other faster and easier } \\
\text { ways to verify the information }\end{array}$ & 8.8 & 0 & 5.9 & 15.0 & 0 & 4.1 & 15.0 \\
\hline The moment has not arisen & 9.9 & 11.8 & 2.9 & 15.0 & 50.0 & 8.2 & 10.0 \\
\hline I haven't been offered a course & 2.2 & 0 & 0 & 5.0 & 0 & 2.0 & 2.5 \\
\hline I haven't found one & 3.3 & 0 & 2.9 & 5.0 & 0 & 4.1 & 2.5 \\
\hline It wasn't online & 1.1 & 5.9 & 0 & 0 & 0 & 2.0 & 0 \\
\hline $\begin{array}{c}\text { Other answers / I do not attend } \\
\text { courses }\end{array}$ & 1.1 & 0 & 2.9 & 0 & 0 & 2.0 & 0 \\
\hline $\begin{array}{c}\text { Do not know / Do not } \\
\text { answer }\end{array}$ & 5.5 & 11.8 & 2.9 & 5.0 & 0 & 6.1 & 5.0 \\
\hline
\end{tabular}

Source: Authors.

Finally, young people believe that the main reasons that fake news is generated include the following: to gain audiences or more visits, followers or clicks (17\%); due to readers lack of training, who do not know how to inform themselves, corroborate the information or be critical of the information received (13.8\%); to attract attention or through interest and convenience (11.8\% respectively); to earn money and manipulate and influence society (both reasons, 10.8\%). None of the other reasons cited exceeded 10\% of mentions (Table 8).

\subsection{Identification of Fake News}

To achieve the second aim of this study, namely to determine whether young Spanish adults know how to verify the content they consume, we first analysed the extent to which young people believe they know how to identify fake news. The results indicate that $59.5 \%$ of 10 young people think they know how to identify fake news very well or quite well $(59.5 \%)$, a perception that increases among men $(63.9 \%)$, with age $(63.1 \%$ from 23 to 25 years) and with the level of studies (third grade, 69.35) (Table 9). 
Table 8. Question 3: Why do you think fake news, that is, rumors, hoaxes, lies, is generated in the media, e.g., TV, social networks, press etc.? (Do not suggest).

\begin{tabular}{|c|c|}
\hline & Total \\
\hline Total Individuals & 501 \\
\hline & $\%$ \\
\hline To gain audience/more visits/more clicks/more followers & 17.0 \\
\hline $\begin{array}{l}\text { Not knowing how to inform oneself/not knowing how to be } \\
\text { critical of the information received/reader's fault/not knowing } \\
\text { how to compare }\end{array}$ & 13.8 \\
\hline To earn money & 10.8 \\
\hline To draw attention/gain fame & 11.8 \\
\hline Manipulate/Influence society & 10.8 \\
\hline Benefits, interests and convenience & 11.8 \\
\hline Social alarm/to frighten/fear & 6.6 \\
\hline Malign intentions/people are bad/jealousy & 4.0 \\
\hline Boredom & 3.0 \\
\hline Errors or intent of the journalist or the information publisher & 4.2 \\
\hline To do harm/to cause damage & 3.8 \\
\hline To deceive/cheat/lie & 3.6 \\
\hline Internet & 2.4 \\
\hline To obscure other news & 2.0 \\
\hline To generate controversy & 4.8 \\
\hline Morbidity & 2.0 \\
\hline Hatred & 1.4 \\
\hline To discredit & 1.4 \\
\hline For fun & 1.2 \\
\hline The reader spreads the information & 0.6 \\
\hline The reader wants to believe the information & 0.8 \\
\hline Other answers & 4.8 \\
\hline Do not know / Do not answer & 5.2 \\
\hline
\end{tabular}

Source: Authors.

Table 9. Question 4: When you read a news item, either because you looked for it on the Internet or it was sent to you through any medium, such as WhatsApp, Instagram, Tik Tok, email, etc., how well do you think you know how to identify whether it is fake news, a rumor, a hoax, a lie?

\begin{tabular}{|c|c|c|c|c|c|c|c|}
\hline & \multirow[b]{2}{*}{ Total } & \multicolumn{3}{|c|}{ AGE } & \multicolumn{3}{|c|}{ EDUCATION } \\
\hline & & $\begin{array}{l}18 \text { to } 19 \\
\text { Years Old } \\
\text { (A) }\end{array}$ & $\begin{array}{l}20 \text { to } 22 \\
\text { Years Old } \\
\text { (B) }\end{array}$ & $\begin{array}{l}23 \text { to } 25 \\
\text { Years Old } \\
\text { (C) }\end{array}$ & $\begin{array}{c}\text { No Studies/First } \\
\text { Grade } \\
\left(D^{*}\right)\end{array}$ & $\begin{array}{l}\text { Second } \\
\text { Grade } \\
\text { (E) }\end{array}$ & $\begin{array}{l}\text { Third } \\
\text { Grade } \\
\text { (F) }\end{array}$ \\
\hline \multirow[t]{2}{*}{ Total } & 501 & 105 & 182 & 214 & 6 & 290 & 205 \\
\hline & $\%$ & $\%$ & $\%$ & $\%$ & $\%$ & $\%$ & $\%$ \\
\hline Very well & 12.8 & 8.6 & 14.3 & 13.6 & 0 & 11.0 & 15.6 \\
\hline Quite well & 46.7 & 41.9 & 46.2 & 49.5 & 0 & 42.8 & $53.7 \mathrm{E}$ \\
\hline Somewhat well & 32.3 & 40.0 & 31.3 & 29.4 & 100.0 & 36.9 & 23.9 \\
\hline Not very well & 5.6 & 5.7 & 4.9 & 6.1 & 0 & 6.2 & 4.9 \\
\hline Not at all well & 2.6 & 3.8 & 3.3 & 1.4 & 0 & 3.1 & 2.0 \\
\hline Top Two Box & 59.5 & 50.5 & 60.5 & 63.1 & 0 & 53.8 & 69.3 \\
\hline Bottom Two Box & 8.2 & 9.5 & 8.2 & 7.5 & 0 & 9.3 & 6.8 \\
\hline
\end{tabular}

Source: Authors.

Foremost among a range of reasons presented to the interviewees as to why they think a news item is fake, is the incongruity or meaninglessness of the news item, an aspect most mentioned among women (87\%), the population aged $18-19$ years $(89.5 \%)$ and among the upper and upper-middle social class (86.7\%). Another notable reason is whether the news comes from social networks such as WhatsApp (58.5\%) and, to a lesser extent, if it 
generates social alarm $(43.7 \%)$, has a very attractive headline $(33.1 \%)$ or contains shocking information $(28.9 \%)$ (Table 10$)$.

Table 10. Question 5: What makes you think that a news item is fake? You can mark multiple answers. (Show list with all items together) (Rotate order of items).

\begin{tabular}{|c|c|c|c|c|c|c|c|}
\hline & & \multicolumn{3}{|c|}{ AGE } & \multicolumn{3}{|c|}{ EDUCATION } \\
\hline & Total & $\begin{array}{l}18 \text { to } 19 \\
\text { Years Old } \\
\text { (A) }\end{array}$ & $\begin{array}{l}20 \text { to } 22 \\
\text { Years Old } \\
\text { (B) }\end{array}$ & $\begin{array}{l}23 \text { to } 25 \\
\text { Years Old } \\
\text { (C) }\end{array}$ & $\begin{array}{c}\text { No Studies/First } \\
\text { Grade } \\
(\mathrm{D} *)\end{array}$ & $\begin{array}{l}\text { Second } \\
\text { Grade } \\
\text { (E) }\end{array}$ & $\begin{array}{c}\text { Third } \\
\text { Grade } \\
\text { (F) }\end{array}$ \\
\hline \multirow[t]{2}{*}{ Total Individuals } & 501 & 105 & 182 & 214 & 6 & 290 & 205 \\
\hline & $\%$ & $\%$ & $\%$ & $\%$ & $\%$ & $\%$ & $\%$ \\
\hline If it generates social alarm & 43.7 & 37.1 & 44.0 & 46.7 & 16.7 & 40.7 & 48.8 \\
\hline $\begin{array}{l}\text { If it comes from social } \\
\text { networks like WhatsApp }\end{array}$ & 58.5 & 51.4 & 61.5 & 59.3 & 33.3 & 54.5 & $64.9 \mathrm{E}$ \\
\hline $\begin{array}{c}\text { If it has an eye-catching } \\
\text { headline }\end{array}$ & 33.1 & 19.0 & $38.5 \mathrm{a}$ & $35.5 \mathrm{~A}$ & 16.7 & 31.4 & 36.1 \\
\hline $\begin{array}{c}\text { If the information is } \\
\text { shocking }\end{array}$ & 28.9 & 22.9 & 26.9 & $33.6 \mathrm{~A}$ & 16.7 & 24.8 & $35.1 \mathrm{E}$ \\
\hline $\begin{array}{l}\text { If it's incongruous, } \\
\text { meaningless }\end{array}$ & 82.0 & $89.5 \mathrm{~B}$ & 78.0 & 81.8 & 66.7 & 81.0 & 83.9 \\
\hline Other answers & 8.2 & 4.8 & 9.3 & 8.9 & 16.7 & 7.9 & 8.3 \\
\hline
\end{tabular}

Source: Authors.

We found that 4 out of 10 young people (39.5\%) are in the habit of always checking whether the news they read is true or fake compared to $55.7 \%$ who check it occasionally, while $4.8 \%$ never verifies it (Table 11 ).

Table 11. Question 6: Do you check whether the news you read is true or fake?

\begin{tabular}{|c|c|c|c|c|c|c|c|}
\hline & \multirow[b]{2}{*}{ Total } & \multicolumn{3}{|c|}{ AGE } & \multicolumn{3}{|c|}{ EDUCATION } \\
\hline & & $\begin{array}{l}18 \text { to } 19 \\
\text { Years } \\
\text { Old } \\
\text { (A) }\end{array}$ & $\begin{array}{l}20 \text { to } 22 \\
\text { Years } \\
\text { Old } \\
\text { (B) }\end{array}$ & $\begin{array}{c}23 \text { to } 25 \\
\text { Years } \\
\text { Old } \\
\text { (C) }\end{array}$ & $\begin{array}{c}\text { No Stud- } \\
\text { ies/First } \\
\text { Grade } \\
\left(D^{*}\right)\end{array}$ & $\begin{array}{l}\text { Second } \\
\text { Grade } \\
\text { (E) }\end{array}$ & $\begin{array}{c}\text { Third } \\
\text { Grade } \\
\text { (F) }\end{array}$ \\
\hline \multirow[t]{2}{*}{$\begin{array}{c}\text { Total } \\
\text { Individuals }\end{array}$} & 501 & 105 & 182 & 214 & 6 & 290 & 205 \\
\hline & $\%$ & $\%$ & $\%$ & $\%$ & $\%$ & $\%$ & $\%$ \\
\hline Always & 39.5 & 36.2 & 39.0 & 41.6 & 16.7 & 39.7 & 40.0 \\
\hline Sometimes & 55.7 & 59.0 & 56.6 & 53.3 & 83.3 & 54.5 & 56.6 \\
\hline Never & 4.8 & 4.8 & 4.4 & 5.1 & 0 & 5.9 & 3.4 \\
\hline
\end{tabular}

Source: Authors.

Regarding the mechanisms that young Spanish adults use to verify information, $49.9 \%$ do so through friends and family (primarily women, $54.5 \%$; young people aged $18-19$ years, $60 \%$; and those with a lower level of studies, second grade studies, $55.3 \%$ ), while $40.7 \%$ check it through specialized websites (StopBulos, Maldita.es), especially young adults between 23 and 25 years old (44.8\%). Other ways of verifying information, cited to a lesser extent and grouped in "Other answers", include consulting other media outlets such as the press, radio or television (13.8\%) and investigating the information and sources (7.8\%), with other methods reaching much lower percentages (Table 12). 
Table 12. Question 7: (Complete if you answer "Always" or "Sometimes" on p. 6) How do you verify whether the information you have searched for or have been sent is true? You can mark multiple answers (Show list with all items).

\begin{tabular}{|c|c|c|c|c|c|c|c|}
\hline & \multirow[b]{2}{*}{ Total } & \multicolumn{3}{|c|}{ AGE } & \multicolumn{3}{|c|}{ EDUCATION } \\
\hline & & $\begin{array}{l}18 \text { to } 19 \\
\text { Years Old } \\
\text { (A) }\end{array}$ & $\begin{array}{l}20 \text { to } 22 \\
\text { Years Old } \\
\text { (B) }\end{array}$ & $\begin{array}{l}23 \text { to } 25 \\
\text { Years Old } \\
\text { (C) }\end{array}$ & $\begin{array}{l}\text { No Studies/First } \\
\text { Grade } \\
\left(D^{*}\right)\end{array}$ & $\begin{array}{l}\text { Second } \\
\text { Grade } \\
\text { (E) }\end{array}$ & $\begin{array}{l}\text { Third } \\
\text { Grade } \\
\text { (F) }\end{array}$ \\
\hline $\begin{array}{l}\text { Individuals Who } \\
\text { Always or Sometimes } \\
\text { Check the News }\end{array}$ & 477 & 100 & 174 & 203 & 6 & 273 & 198 \\
\hline & $\%$ & $\%$ & $\%$ & $\%$ & $\%$ & $\%$ & $\%$ \\
\hline $\begin{array}{l}\text { I check it with family or } \\
\text { friends }\end{array}$ & 49.7 & $60.0 \mathrm{C}$ & 48.9 & 45.3 & 50.0 & $55.3 \mathrm{~F}$ & 41.9 \\
\hline $\begin{array}{l}\text { I verify it on StopBulos, } \\
\text { Maldita.es or similar } \\
\text { websites }\end{array}$ & 40.7 & 31.0 & 41.4 & $44.8 \mathrm{~A}$ & 16.7 & 39.2 & 43.4 \\
\hline Other answers & 35.4 & 28.0 & 35.1 & 39.4 & 33.3 & 30.8 & $41.9 \mathrm{E}$ \\
\hline $\begin{array}{c}\text { Do not know/Do not } \\
\text { answer }\end{array}$ & 0.8 & 0 & 1.1 & 1.0 & 0 & 0.7 & 1.0 \\
\hline
\end{tabular}

Source: Authors.

When asked about the degree of importance they attach to the actions of organizations to verify the information, the results indicate that the reputation of the media organization is the most important factor in determining whether the news is true or fake (Top Two Box $75.2 \%)$, a view held primarily by young people between 23 and 25 years of age $(81.8 \%)$ and those with third grade studies $(81 \%)$. In contrast, the least relevant factor is the author of the news item (Bottom Two Box 36.5\%) (Table 13).

Table 13. Question 8: Think of the moment when you are reading a news item that you have searched for or have been sent. How much importance do you attach to each of the following in order to know whether the news item is true or fake? (Rotate items and show scale).

\begin{tabular}{|c|c|c|c|c|c|}
\hline & & & FACTORS & & \\
\hline & $\begin{array}{c}\text { The Reputation of } \\
\text { the Media } \\
\text { Organization (A) }\end{array}$ & $\begin{array}{l}\text { The Name of the } \\
\text { Author of the } \\
\text { News Item } \\
\text { (B) }\end{array}$ & $\begin{array}{l}\text { The Person or } \\
\text { Entity That Sent } \\
\text { the News Item } \\
\text { (C) }\end{array}$ & $\begin{array}{l}\text { The Sources } \\
\text { Cited in the } \\
\text { News Item } \\
\text { (D) }\end{array}$ & $\begin{array}{c}\text { The Date of } \\
\text { Publication } \\
\text { (E) }\end{array}$ \\
\hline \multirow[t]{2}{*}{ Total } & 501 & 501 & 501 & 501 & 501 \\
\hline & $\%$ & $\%$ & $\%$ & $\%$ & $\%$ \\
\hline A lot & $35.9 \mathrm{BCE}$ & 7.8 & $21.6 \mathrm{~B}$ & $31.9 \mathrm{BCE}$ & $19.4 \mathrm{~B}$ \\
\hline Quite a lot & 39.3 B & 21.8 & $37.1 \mathrm{~B}$ & $34.3 \mathrm{~B}$ & $35.7 \mathrm{~B}$ \\
\hline Some & 18.8 & $33.9 \mathrm{AD}$ & $29.7 \mathrm{AD}$ & 23.4 & $30.9 \mathrm{AD}$ \\
\hline Not very much & 3.2 & 23.6 ACDE & $8.0 \mathrm{~A}$ & $6.0 \mathrm{~A}$ & $9.6 \mathrm{AD}$ \\
\hline None & 2.8 & 13.0 ACDE & 3.6 & 4.4 & 4.4 \\
\hline Top Two Boxes & $75.2 \mathrm{BCDE}$ & 29.5 & $58.7 \mathrm{~B}$ & 66.3 BCE & $55.1 \mathrm{~B}$ \\
\hline Bottom Two Boxes & 6.0 & 36.5 ACDE & $11.6 \mathrm{~A}$ & $10.4 \mathrm{~A}$ & $14.0 \mathrm{~A}$ \\
\hline
\end{tabular}

Source: Authors.

\subsection{Dissemination of Fake News}

We found $87.6 \%$ of young people have at some time received fake news, especially women $(91.5 \%)$, those with the highest level of education $(93.7 \%)$ and social class $(90.7 \%)$, while $6.6 \%$ claim to have spread fake news at some point, compared to $93.5 \%$ who do not tend to spread such news (Table 14). 
Table 14. Question 9: Now think specifically about what you do when you receive or forward fake news. Have you ever received, through any medium, fake news? Q.10: Have you ever spread a fake news item through any medium knowing that it was fake?

\begin{tabular}{|c|c|c|c|c|c|c|c|}
\hline & \multirow[b]{2}{*}{ Total } & \multicolumn{3}{|c|}{ AGE } & \multicolumn{3}{|c|}{ EDUCATION } \\
\hline & & $\begin{array}{l}18 \text { to } 19 \\
\text { Years Old } \\
\text { (A) }\end{array}$ & $\begin{array}{l}20 \text { to } 22 \\
\text { Years Old } \\
\text { (B) }\end{array}$ & $\begin{array}{l}23 \text { to } 25 \\
\text { Years Old } \\
\text { (C) }\end{array}$ & $\begin{array}{l}\text { No Studies/First } \\
\text { Grade } \\
\left(D^{*}\right)\end{array}$ & $\begin{array}{l}\text { Second } \\
\text { Grade } \\
\text { (E) }\end{array}$ & $\begin{array}{c}\text { Third } \\
\text { Grade } \\
\text { (F) }\end{array}$ \\
\hline Total & 501 & 105 & 182 & 214 & 6 & 290 & 205 \\
\hline & $\%$ & $\%$ & $\%$ & $\%$ & $\%$ & $\%$ & $\%$ \\
\hline Have received fake news & 87.6 & 82.9 & 90.7 & 87.4 & 66.7 & 83.8 & $93.7 \mathrm{E}$ \\
\hline Have spread fake news & 6.6 & 8.6 & 6.6 & 5.6 & 0 & 6.9 & 6.3 \\
\hline
\end{tabular}

Source: Authors.

Regarding whether fun, boredom or the prospect of generating more social relations influence the dissemination of fake news, the data indicate that $51.5 \%$ never do it because they enjoy it, as an excuse to relate to people $(72.7 \%)$ or out of boredom $(60.6 \%)$. On the other hand, $48.5 \%$ of those who spread fake news knowingly always did so to warn others that the item was fake news (Table 15).

Table 15. Question 11: Complete Q.11 if you answer "Yes" on q. 10) How often do you spread fake news for the following reasons? (Show phrases randomly).

\begin{tabular}{ccccc}
\hline & \multicolumn{3}{c}{ MOTIVES } \\
\hline & $\begin{array}{c}\text { I Enjoy It } \\
\text { (A) }\end{array}$ & $\begin{array}{c}\text { It's an Excuse to } \\
\text { Socialize with People } \\
\text { (B) }\end{array}$ & $\begin{array}{c}\text { I Do It Only When I'm } \\
\text { Bored } \\
\text { (C) }\end{array}$ & $\begin{array}{c}\text { To Warn That It's } \\
\text { Fake News } \\
\text { (D) }\end{array}$ \\
\hline $\begin{array}{c}\text { Individuals Who Have } \\
\text { Knowingly Spread Fake News }\end{array}$ & 33 & 33 & 33 & \\
\hline Always & $\%$ & $\%$ & $\%$ & \\
Sometimes & 6.1 & 12.1 & 15.2 & \\
Never & $42.4 \mathrm{~B}$ & 15.2 & 24.2 & $48.5 \mathrm{ABC}$ \\
$42.4 \mathrm{~B}$ \\
9.1
\end{tabular}

Source: Authors.

Finally, approximately 4 out of 10 young people always encourage their contacts / friends / family members to disseminate information only if they have first verified it (45.1\%); women stand out here, as well as young people with third-grade studies and those from high and medium-high social classes. When they receive a news item and realize that it is or may be fake news, 5 out of 10 young people always warn the person who sent it to them that it is or may be fake $(55.1 \%)$, with strongest showing from the same segments: women, young people with third-grade studies and those from high and medium-high social class. Seven out of 10 respondents eliminate news from their social networks when they know it to be fake (75\%), especially young people from high and medium-high social classes (Table 16). 
Table 16. Question 12: Do you encourage your contacts/friends/family to share information only if they have verified it? Question 13: When you receive a news item and you realize that it is or may be fake news, do you tell the person who sent it to you that it is or may be fake? Question 14. Do you delete news from your social networks that you know to be fake?

\begin{tabular}{cccc}
\hline & $\begin{array}{c}\text { Question 12 } \\
\text { Encourage } \\
\text { Verification }\end{array}$ & $\begin{array}{c}\text { Question 13 } \\
\text { Warn Sender It Is Fake }\end{array}$ & $\begin{array}{c}\text { Question 14 } \\
\text { Remove Fake News }\end{array}$ \\
\hline Total Individuals & $\mathbf{5 0 1}$ & $\mathbf{5 0 1}$ & $\mathbf{5 0 1}$ \\
\hline Always & $\%$ & $\%$ & $\%$ \\
Sometimes & 45.1 & 55.1 & 75.0 \\
Never & 34.9 & 36.7 & 19.4 \\
\hline
\end{tabular}

Source: Authors.

\section{Discussion and Conclusions}

Young Spanish adults are aware of the importance of training in order to know how to determine the veracity of information. This degree of awareness is probably, as the Digital News Report Spain [38] indicated, a result of the fact that young people between 18 and 24 believe that most news cannot be trusted, a finding we corroborated when we asked them about the causes of disinformation; young Spanish adults indicated that it is a result of a lack of critical knowledge when consuming information, this reason being ranked second among the reasons provided: $13.8 \%$ believe that not knowing how to get informed, not knowing how to contrast content, and not being critical of the information received is one of the main reasons why fake news is generated. This is interpreted as apportioning blame to the illiterate reader given that their lack of training contributes to achieving the objectives of those who create fake news items in order to gain an audience, generate more visits and gain more followers (17\%). Training is necessary: to acquire the media competencies to tell the truth from falsehoods; to stop the profits made by the creators of fake news; and to combat one of the reasons why they consider such information is generated: readers that lack the ability to discern disinformation.

However, it is highly significant that, although they attach great importance to media literacy, 8 out of 10 young people do not know of any training program, which implies that they have not attended one either. These results allow us to conclude that there are problems surrounding the publicity of the programs offered because, despite being abundant, young adults between 18 and 25 years old remain unaware of them. This calls for measures to be taken in order to improve their impact on this age group.

However, being aware of courses does not mean that they are going to undertake one either, since only 2 out of 10 young people who are aware of a fake news learning program end up taking one. Those who have mainly did so for free in universities and institutes, allowing us to conclude that only those who have studied in educational centres providing such teaching programs have taken one. This theory is strengthened by the observation that young adults do not take the initiative to find these courses and that the main reasons they fail to enrol include not being interested in the course, a lack of time, or because they believe that they already know how to discern real news from fake. Thus, we believe that educational centres of all levels should be the main places to carry out such training since they eliminate the problem of time and students' refusal to undertake one in favour of acquiring critical knowledge of information. In this regard, UNESCO stresses that this training must be undertaken in the academic sector.

Similarly, due to the lack of training in this age group, we can confirm, regardless of gender or level of studies, the presence of a "media literacy crisis" and the urgent need for "transmedia literacy" Scolari [39] or of a media and informational educommunication. Such training is necessary because young people between 18 and 25 years of age believe that, despite not being aware of or having taken a course, they know how to identify the fake news, with 6 out of 10 believing they know how to do so very well or quite well. However, when asked how they identify fake news, for 5 out of 10 young people the 
most representative answer is asking family and friends. The study "The conditioning factors of disinformation and proposed solutions against its impact based on the degrees of vulnerability of the groups analysed" [40] carried out by the Centro de Estudios de San Pablo CEU revealed the trust they usually have in their relatives, friends and closest personal references, believing the information that comes through them to be reliable and credible.

Thus, young Spanish adults believe they know how to identify fake news but do not use the optimal tools for its verification. These results are corroborated by those provided by the "Study on the impact of fake news in Spain" [41] which revealed that more than fifty percent of young people believed they knew how to identify fake news but that only $4 \%$ actually knew how to, and by those of Herrero, Conde, Tapia and Varona [7], who concluded that young adults have difficulties in differentiating the veracity of sources. Therefore, these data lead us to believe that it is necessary to create more activities and to provide support to socio-educational projects in order to allow young Spanish adults to attend courses, to take the initiative to look for such courses autonomously and to raise their interest in them. According to the data obtained, they also play a role in the creation of fake news, as they are a vulnerable sector.

Young Spanish adults represent an age group that does not always verify information. They primarily suspect the credibility of those news stories that are incongruous or nonsensical, or that reach them through WhatsApp. In second place are those news stories that have an eye-catching headline, that generate social alarm or that are shocking; the students did not, however, indicate any actions various organizations stress as being necessary to perform, such as investigating the reputation of the media outlet, the sources or the date of publication. However, when asked about these actions, they indicated the reputation of the media organization and the sources as being very important. Therefore, while these verification actions are not ranked, young Spanish adults do understand their degree of importance. Therefore, the regular application of these actions vis-à-vis critical information consumption must be encouraged in training programs.

However, it is significant that although they receive a lot of fake news, as the study by Panda Security [6] also revealed, young Spanish people do not tend to spread it. These findings are corroborated by those of Carballo and Marroquín [29], who observed that three quarters of the young adults analysed reported that they do not spread fake information, an observation also confirmed internationally by Guess, Nagler and Tucker [42], who found that during the Trump elections "users over 65 years old shared seven times more articles from fake news domains than the youngest age group" (p. 1).

Thus, although there is a certain tendency to criticize the younger generations, this has more to do with fear than a real analysis of these younger generations. They are attacked for being connected to the Internet all day sharing any type of information. Not only do they tend not to spread it, they also delete it from their social networks, an observation also made in the study by Carballo and Marroquín (2020) [29].

Therefore, in agreement with Buckingham [43], we conclude that an implementation of news literacy and coherent and rigorous "educational" programs is needed. Reports indicate that in 2022 fake information will be habitually consumed and that although young adults are aware of the dangers of fake news, they are not trained in verifying information or undertaking critical consumption.

It is important that such training be undertaken in educational centres and should focus mainly on teaching students how to identify fakes news. Moreover, young adults need to be taught the importance of not spreading it. In addition, it should be stressed to them that although spreading fake news is not a deficiency in this age group, believing so without having training or mastering effective techniques is. Nonetheless, these curricular programs should also teach young people that they should not get carried away with spreading it simply for the fun of it, as this is one of the main reasons that leads them to sharing fake information on the few occasions they do. Similarly, they must be trained to be critical of information, checking the veracity of the information in each news item 
by e.g., checking the source and the date (among other actions recommended by various organizations), and not just when they believe it to be of doubtful origin.

Ranieri, Si Stasio and Bruni (2018) [30] confirm that young adults who take training courses increase their skills. They analysed the results obtained in workshops on fake news provided to students at the University of Florence (2017-2018) and concluded that they are useful because they allow optimal information literacy.

Future studies should examine the reasons preventing young Spanish adults between 18 and 25 years old from knowing about training courses on fake news, aggregate the programs being undertaken in educational centres in Spain, and carry out comparative studies in across Europe.

Author Contributions: A.M.d.V.D., A.B.B. and J.S.S. contributed to the writing and editing of this research article. All authors have read and agreed to the published version of the manuscript.

Funding: This research was funded with the support of the MULTICULTCOM research group (Communication and conflict in a multicultural society) of the Universitat Abat Oliba CEU (FUSPBSPPC24/2015).

Institutional Review Board Statement: Not applicable.

Informed Consent Statement: Not applicable.

Data Availability Statement: The data presented in this study are available on request from the corresponding author.

Conflicts of Interest: The authors declare no conflict of interest.

\section{References}

1. Fernández, N. Fake News: Una Oportunidad para la Alfabetización Mediática. 2017. Available online: https://nuso.org/ articulo/fake-news-una-oportunidad-para-la-alfabetizacion-mediatica/ (accessed on 15 April 2020).

2. Ipsos Public Affairs. Report Fakes News, Filter Bubbles, Post-Truth and Trust. 2018. Available online: https://www.ipsos.com/sites/ default/files/ct/news/documents/2018-09/fake-news-filter-bubbles-post-truth-and-trust.pdf (accessed on 5 August 2020).

3. Gartner. Garther Top Strategic Predictions for 2018 and Beyond. 2017. Available online: https://www.gartner.com/ smarterwithgartner/gartner-top-strategic-predictions-for-2018-and-beyond/ (accessed on 5 August 2020).

4. Catalina García, B.; García Jiménez, A.; Montes Vozmediano, M. Jóvenes y consumo de noticias a través de Internet y los medios sociales. Histor. Comunic. Soc. 2015, 2, 601-619. [CrossRef]

5. Digital New Reports. Digital New Report España 2020. 2020. Available online: https://www.digitalnewsreport.es/category/20 20/ (accessed on 5 August 2020).

6. Panda Security. La Mitad de los Españoles Recibe "Fake News" con Frecuencia. 2020. Available online: https://www. pandasecurity.com/es/mediacenter/mobile-news/espanoles-fake-news / (accessed on 10 September 2020).

7. Herrero-Díaz, P.; Conde-Jiménez, J.; Tapia-Frade, A.; Varona-Aramburu, D. The credibility of online news: An evaluation of the information by university students / La credibilidad de las noticias en Internet: Una evaluación de la información por estudiantes universitarios. Cult. Educ. 2019, 31, 407-435. [CrossRef]

8. Vázquez-Herrero, J.; Vizoso, A.; López-García, X. Innovación tecnológica y comunicativa para combatir la desinformación: 135 experiencias para un cambio de rumbo. Prof. Inf. 2019, 28, 1-12. [CrossRef]

9. Palomo, B.; Sedano, J. WhatsApp como herramienta de verificación de fake news. El caso de B de Bulo. WhatsApp Herramienta Verif. Fake News. Caso B Bulo. Revista Latina de Comunicación Social. 2018, 73, 1384-1397. [CrossRef]

10. Bernal-Triviño, A.; Clares-Gavilán, J. Uso del móvil y las redes sociales como canales de verificación de fake news. El caso de Maldita.es. Prof. Info. 2019, 28, 1-8. [CrossRef]

11. Katsaounidou, A.; Dimoulas, C.; Veglis, A. Cross-Media Authentication and verification: Emerging Research and Opportunities; Editorial IGI Global: Hershey, PA, USA, 2018.

12. Ruiz, M.U.; García, L.P.; Verdú, F.J.M. Fact checking: Un nuevo desafío del periodismo. Prof. Inf. 2018, 27, 733-741. [CrossRef]

13. Blanco-Herrero, D.; Arcila-Calderón, C. Deontología y noticias falsas: Estudio de las percepciones de periodistas españoles. Prof. Inf. 2019, 28, 1-13. [CrossRef]

14. Rubio-Moraga, A.L.; Dáder-García, J.L. El Futuro del Periodismo en Tiempos de Posverdad. In La Posverdad. Una Cartografía de los Medios, las Redes y la Política; Aparici, R., García-Marín, D., Eds.; Gedisa: Barcelona, Spain, 2019.

15. Wagner, M.C.; Boczkowski, P.J. The Reception of Fake News: The Interpretations and Practices That Shape the Consumption of Perceived Misinformation. Digit. J. 2019, 7, 870-885. [CrossRef]

16. Alonso, M. Fakes news: Desinformación en la era de la sociedad de la información. Ámbitos 2019, 45, $29-52$. 
17. White, A. Fake News: It's Not Bad Journalism, It's the Business of Digital Communications, Ethical Journalism Network. 2017. Available online: https:/ / ethicaljournalismnetwork.org/fake-news-bad-journalism-digital-age (accessed on 20 August 2020).

18. Dictionary Cambridge. 2020. Available online: https://dictionary.cambridge.org/es/diccionario/ingles/fake-news (accessed on 20 August 2020).

19. Amoros, M. Fake News: La Verdad de las Noticias Falsas; Editorial Plataforma: Barcelona, Spain, 2018.

20. Mendiguren, T.; DaSilva, J.P.; Meso-Ayerdi, K. Actitud ante las Fake News: Estudio del caso de los estudiantes de la Universidad del País Vasco. Rev. Común. 2020, 19, 171-184. [CrossRef]

21. Edson, C.T., Jr.; Zheng, L.; Richard, L. Defining “Fake News”. Digit. J. 2018, 6, 137-153.

22. Martens, B.; Aguiar, L.; Gomez-Herrera, E.; Mueller-Langer, F. The Digital Transformation of News Media and the Rise of Disinformation and Fake News; JCR Join Research Centre: Sevilla, Spain, 2018.

23. Rodríguez, C. Una reflexión sobre la epistemología del fact-cheking journalism: Retos y dilemas. Rev. Común. 2020, 19, 243-258.

24. Rodríguez, C. No diga fake news, di desinformación: Una revisión sobre el fenómeno de las noticias falsas y sus implicaciones. Rev. Comun. 2019, 40, 65-74. [CrossRef]

25. Comisión Europea. Unión Europea vs. Desinformación. 2019. Available online: https://ec.europa.eu/spain/news/20191105_euvs-disinformation_es (accessed on 1 April 2020).

26. Tuñon, J.; Bouza, L.; Carral, U. Comunicación Eurpea. ¿A Quién le Doy al Like para Hablar de Europa? Editorial Dickinson: Madrid, Spain, 2019.

27. Figueira, J.; Santos, S. Percepción de las noticias falsas en universitarios de Portugal: Análisis de su consumo y actitudes. Prof. Inf. 2019, 28, 1-7. [CrossRef]

28. Sobral, F.; Salomé, N. Información falsa en la red: La perspectiva de un grupo de estudiantes universitarios de comunicación en Portugal. Prisma Soc. 2020, 29, 17-194.

29. Carballo, W.; Marroquín, A. Alfabetización mediática y consumo noticioso entre jóvenes salvadoreños en tiempos digitales. ALCANCE Rev. Cubana Inf. Comun. 2020, 9, 144-155.

30. Ranieri, M.; Di Stasio, M.; Bruni, I. Insegnare e apprendere sulle fake news. Uno studio esplorativo in contesto universitario. Media Educ. 2018, 9, 94-111.

31. Pineda, H.; Jima-González, A.; Paradera, M.; García, C.; Parra, E.; Loaiza, K.; Areiza, S.; Ostina, T.; Agudelo, A.; Giraldo, S.; et al. ¿Preparados para las Fake News? Un estudio exploratorio de la comunidad universitaria del Tecnológico de Antioquia. En-Contexto 2019, 8, 1-39.

32. Malaquías, A.; Lízbeth, L.; Pérez Rivera, D.; Rodolfo, O.; Villegas, M.C. Fake news y el impacto en jóvenes universitarios y de educación básica en relación con las redes sociales en Mexicali. 2019. Available online: https://www.academia.edu/40943073 /Universidad_Aut\%C3\%B3noma_de_Baja_California (accessed on 20 May 2020).

33. Institucional Repository of the University of Huelva. Conspiracy Theories and Disinformation in Andalusia Executive Report. 2019. Available online: http://rabida.uhu.es/dspace/bitstream/handle/10272/16291/Conspiracy\%20Theories\%20 Disinformation\%20in\%20Andalusia_ExecutiveReport\%202019.pdf?sequence=2 (accessed on 1 April 2020).

34. Berganza, M.R.; Ruiz, J.A. Investigar en Comunicación: Guía Práctica de Métodos y Técnicas de Investigación Social en Comunicación; McGraw Hill: Madrid, Spain, 2005.

35. Hair, J.; Bush, R.; Ortinau, D. Investigación de Mercados en un Ambiente de Información Digital; Mc Graw Hill: Ciudad de México, Mexico, 2010.

36. Alwin, D.F. Margins of Error: A Study of Reliability in Survey Measurement; John Wiley \& Sons: Hoboken, NJ, USA, 2007.

37. Wimmer, R.; Dominick, J.R. Mass Media Research: An Introduction; Wadsworth: Boston, MA, USA, 2011.

38. Digital New Reports. Digital New Report España 2018. 2018. Available online: https://www.digitalnewsreport.es/category/20 18/ (accessed on 5 August 2020).

39. Scolari, C. Estrategias de aprendizaje informal y competencias mediáticas enla nueva ecología de la comunicación. Telos 2016, 103, 1-9.

40. Gelado-Marcos, R.; Puebla-Martínez, B. Estudio de los Factores Condicionantes de la Desinformación. Propuesta de Soluciones Contra su Impacto en Función de los Grados de Vulnerabilidad de los Grupos Analizados. 2019. Available online: https: / / laboratoriodeperiodismo.org/estudio-sobre-la-desinformacion/ (accessed on 10 June 2020).

41. I Estudio Sobre las Fakes News en España. 2017. Available online: https://d3vjcwm65af87t.cloudfront.net/novacdn/ EstudioPescanova.pdf (accessed on 10 June 2020).

42. Guess, A.; Nagler, J.; Tucker, J.A. Less than you think: Prevalence and predictors of fake news dissemination on Facebook. Sci. Adv. 2019, 5, eaau4586. [CrossRef]

43. Buckingham, D. Teaching media in a 'post-truth' age: Fake news, media bias and the challenge for media/digital literacy education / La enseñanza mediática en la era de la posverdad: Fake news, sesgo mediático y el reto para la educación en materia de alfabetización mediática y digital. Cult. Educ. 2019, 31, 213-231. 